\title{
Population structure and maturity stages of Fritillaria borealis (Appendicularia, Tunicata): seasonal cycle in Ushuaia Bay (Beagle Channel)
}

\author{
María Laura Prestal , Mónica Susana Hoffmeyer ${ }^{2}$, Fabiana Lia Capitanio ${ }^{1}$
}

\author{
${ }^{1}$ Instituto de Biodiversidad y Biología Experimental y Aplicada, Consejo Nacional de Investigaciones Científicas y Técnicas, \\ Universidad de Buenos Aires (IBBEA, CONICET - UBA) \\ (Intendente Güiraldes 2160 - Ciudad Universitaria - C1428EG, Argentina) \\ ${ }^{2}$ Instituto Argentino de Oceanografía, Consejo Nacional de Investigaciones Científicas y Técnicas, Universidad Nacional del Sur \\ (IADO, CONICET - UNS) \\ (Camino La Carrindanga km 7,5, B8000FWB, Bahía Blanca, Argentina) \\ *Corresponding author: mlpresta@hotmail.com
}

\section{Abstract}

Fritillaria borealis is a cosmopolitan species, very frequent in sub-antarctic and antarctic waters. The objective of this paper was to analyze its size structure and maturity stages at two sites in Ushuaia Bay: a coastal site exposed to anthropogenic pressure (E1) and a reference site (E2) located in the external zone of the bay. Zooplankton was collected during the 2012 seasonal cycle. The sampling method involved the use of a $67 \mu \mathrm{m}$-mesh net. Appendicularians were classified in four maturity stages: I) undifferentiated gonads, II) testis and ovary differentiated, III) expanded testis, IV) discharged testis, expanded ovary. Our results showed that the highest densities of $F$. borealis occurred in spring and summer at both sites; coinciding with high values of chlorophyll- $a$. The percentage of juveniles (I and II) exhibited a spatial and temporal pattern similar to that observed for chlorophyll- $a$ values. During spring-summer, juveniles and mature specimens (III and IV) showed a greater gonadal development than those individuals found in autumn-winter. In conclusion, the mismatching in the population structure and the pattern of densities of $F$. borealis between coastal and external zones would suggest the existence of two sub-populations susceptible to the influence of the anthropogenic impact in the bay.

Descriptors: Appendicularians, Maturity stages, Beagle Channel.

\section{RESUMO}

Fritillaria borealis é uma espécie cosmopolita, muito frequente em águas subantárticas e antárticas. O objetivo do trabalho foi analisar a estrutura de tamanhos e estádios de maturação da espécie em dois locais da Bahía Ushuaia: um costeiro, sujeito à pressão humana (E1), e um local de referência (E2) na zona externa da baia. O zooplâncton foi coletado no ciclo sazonal 2012. O método de amostragem envolveu o uso de uma rede de 67 micrômetros de abertura de malha. As apendiculárias foram classificadas em quatro estádios de maturação: I) gônada indiferenciada, II) testículo e ovário diferenciados, III) testículo expandido, IV) testículo descarregado, ovário expandido. Nossos resultados mostraram que as maiores densidades de $F$. borealis ocorreram na primavera e no verão nos dois locais, coincidindo com altos valores de clorofila- $a$. A percentagem dos juvenis (I e II) mostrou um padrão espacial e temporal semelhante ao observado para os valores de clorofila- $a$. Na primavera-verão, juvenis e maduros (III e IV) tiveram um desenvolvimento gonadal superior aos encontrados no outono-inverno. Em conclusão, o desacoplamento nas estruturas populacionais e nos padrões de densidade de $F$. borealis entre áreas costeiras e externas sugere a existência de diferentes subpopulações suscetíveis à influência do impacto humano.

Descritores: Apendiculárias, Estádios de maturação, Canal de Beagle. 


\section{INTRODUCTION}

The genus Fritillaria is currently represented by 26 species (FENAUX 1998; FENAUX et al., 1998), several of them being important components of the marine zooplankton. They are protandrous hermaphrodites and the shape and disposition of the gonads differ between species (FENAUX, 1967).

Fritillaria borealis (LOHMANN, 1896) is a small sized cosmopolitan species which presents short generation times and high rates of growth and reproduction (FENAUX, 1976). In this species, the ovary is spherical and the testis is positioned behind the ovary on the same longitudinal axis (FENAUX, 1967; MARTINUCCI et al., 2005). WYATT (1973) studied the spatial distribution of appendicularians in the North Sea and described their sexual development on the basis of 402 specimens collected between mid-winter and early spring. Based on the morphology of the gonads, that author defined four maturity stages but within them, stage II presented extremely broad characteristics. Thus, this stage ranged from juveniles with an incipient ovary and testis differentiation to adults with a mature testis. Regarding stages I and III, they included, respectively, juveniles with as yet undifferentiated testis and ovary and adults with mature ovaries. In stage IV, individuals with both gonads discharged were included, although they die immediately after this event has occurred. To our knowledge, this is the only research on the life cycle of $F$. borealis.

In the Southwestern Atlantic Ocean, F. borealis is a very common species. However, probably due to its fragility, knowledge about its ecology is scarce. Some studies performed in the northern shelf waters of the Argentine Sea, have shown that in this area, temporal variations of $F$. borealis density are associated with temperature variations. During the seasonal cycle at a Buenos Aires coastal station $\left(38^{\circ} 28^{\prime} \mathrm{S}, 57^{\circ} 41^{\prime} \mathrm{W}\right)$, its highest densities occurred during the autumn-winter period, coinciding with the lowest temperatures (CAPITANIO et al., 2008). Also, in the subAntarctic region, AGUIRRE et al. (2012), who studied the seasonal variation in the composition and abundance of metazooplankton in different bays of the Beagle Channel, reported that this species is widely distributed in these coastal zones. F. borealis was an important component of zooplankton in spring (November), coinciding with maximum values of chlorophyll- $a$. In Ushuaia Bay, our study area, BIANCALANA (2008) studied the seasonal and spatial differences in the composition and abundance of holo and meroplankton and their relation to environmental conditions. That author observed a higher frequency of occurrence of this species in summer (March). This far, no population studies of $F$. borealis have been conducted in this bay.

As a consequence of an unplanned and rapid economic development as well as a high demographic growth, the coastal area of Ushuaia Bay suffers nowadays diverse anthropogenic pressures; among them, the discharge of sewage and industrial effluents without any treatment (ESTEVES; AMIN, 2001). The main contribution of sewage pollution comes from Encerrada Bay, which receives approximately $50 \%$ of the sewage of Ushuaia (ESTEVES; AMIN, 2001; GIL et al., 2011).

Considering the above mentioned fact, in this study we propose to compare the development of $F$. borealis populations at a coastal site and at a reference site located in the external zone of Ushuaia Bay, along a seasonal cycle. To achieve this goal we propose: 1) to redefine the maturity stages of $F$. borealis based on the morphology and morphometry of the gonads; emphasizing the functional distinction between juveniles and adults; 2) to determine maturity stages and size structures of the population and analyze its relationship with the environmental characteristics in each season at both study sites.

\section{MATERIAL AND METHODS}

\section{STUDY AREA}

Ushuaia Bay is located in the Isla Grande de Tierra del Fuego (Argentina) on the northern coast of the Beagle Channel $\left(54^{\circ} 79^{\prime} \mathrm{S}-68^{\circ} 22^{\prime} \mathrm{W}\right)$. It presents a total area of $21.7 \mathrm{~km} 2$ (LUCHINI; WICKI, 2002). The bay is characterized by its irregular depth ranging from 6 to $30 \mathrm{~m}$ in the western zone and from 100 to $170 \mathrm{~m}$ in the eastern zone near the Beagle Channel (DIODATO, 2008). Current velocities range from 5.5 to $16.3 \mathrm{~cm} / \mathrm{s}$ (BALESTRINI et al, 1998). Salinity reaches maximum values during winter, decreasing in spring and summer due to the melt water effect on the flow of different fresh water inputs, mainly those of Grande and Buena Esperanza Streams (ITURRASPE et al., 1989).

\section{Collection AND PROCESSING OF SAMPLES}

Samplings were conducted during the 2012 seasonal cycle: late summer (07-08 March), late autumn (18-19 June), late winter (25-26 September) and late spring (10-11 December). Two sampling sites were selected: a coastal 
site (E1) $\left(54^{\circ} 48.51^{\prime} \mathrm{S}, 68^{\circ} 17.71^{\prime} \mathrm{W}\right)$ and a site located in

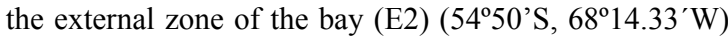
(Figure 1). Samples were collected aboard a motor boat. At each site, the mesozooplankton was sampled using a 67 $\mu \mathrm{m}$ - mesh net by means of oblique hauls from a maximum depth of $30 \mathrm{~m}$ to the surface at a speed of approximately 1 knot for 5 minutes. The volume of water filtered by the net was estimated using a mechanical General Oceanics ${ }^{\circledR}$ flowmeter. Samples were preserved in 5\% formalin. Temperature and salinity at the surface and $10 \mathrm{~m}$ depth were measured with a Hanna Hi 9828 multiparameter probe. Also, $500 \mathrm{ml}$ of seawater was collected in bottles at those depths to estimate the concentration of chlorophyll-a. Filtrations were performed through Whatman GF/F filters ( $0.7 \mu \mathrm{m}$ pore) and gentle vacuum. Filters were stored in the dark at $-18^{\circ} \mathrm{C}$ until extraction. Extractions of chlorophyll- $a$ were made with $90 \%$ acetone and their concentrations were determined by fluorometry in accordance with HOLM-HANSEN et al. (1965).

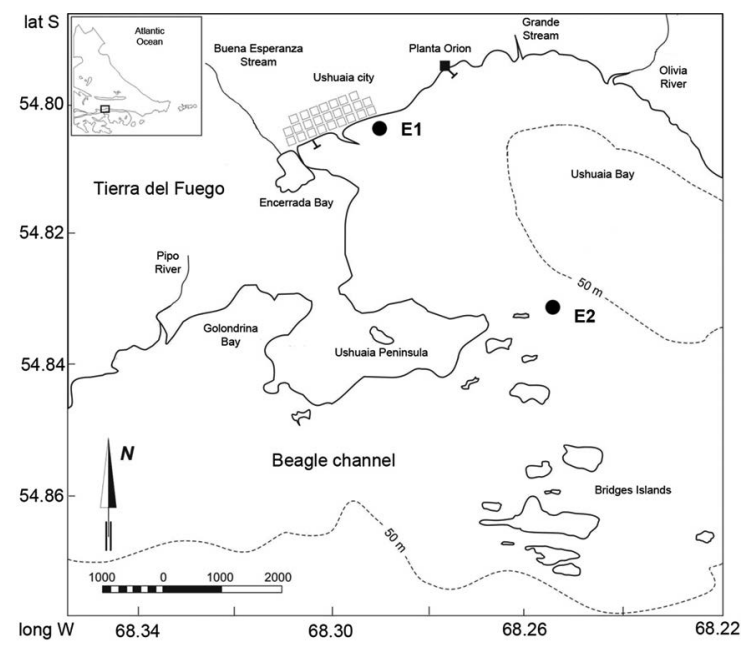

Figure 1. Location of study sites in Ushuaia Bay (Beagle Channel). E1. coastal site, E2. external site.

The quantification of $F$. borealis was carried out under a stereomicroscope by examining aliquots extracted randomly from the homogenized samples until $10 \%$ of each sample had been completed (BOLTOVSKOY, 1981). When $F$. borealis was scarcely abundant, a total count was performed.

In order to characterize maturity stages and size structure in each season, subsamples of at least 100 individuals from each site were employed. For each specimen, length of trunk and length and maximum width of gonad were measured under an optical microscope with a micrometric ocular. Photographs corresponding to each maturity stage were taken with a Sony DSC P-200 camera attached to the optical microscope.

Gonadal development (i.e., measured as gonadal length) of individuals corresponding to each maturity stage was compared between seasons and study sites. For this propose, an Analysis of Covariance (ANCOVA) was performed using the length of the trunk as covariate. Previously, the assumptions of homogeneity of variance and normality of the covariate as well as the assumption of homogeneity of slopes (i.e., no interaction between covariate and treatment) were verified. In cases in which all or some of the assumptions were not verified, Ln $(\mathrm{Lt})$ or $\log 10(\mathrm{Lt}+1)$ transformations were applied. A significance level of 0.05 was used, excepting in three cases in which a 0.01 level was employed due to the lack of assumptions after data transformation. InfoStat packages were used for data analysis.

\section{RESULTS}

SEASONAL VARIATION OF TEMPERATURE, SALINITY AND CHLOROPHYLL- $A$ AT THE COASTAL AND EXTERNAL SITES OF USHUAIA BAY

Values of temperature showed a clear seasonal pattern decreasing in autumn-winter and increasing in spring-summer. Differences between surface temperature and that at $10 \mathrm{~m}$ depth were slight $\left(<0.5^{\circ} \mathrm{C}\right)$ at both sites. Generally, temperature values were slightly higher at E1 (Figure 2A).

Maximum and minimum values of salinity were recorded in late winter and late summer, respectively. At E1, an extremely low salinity value was registered at 10 $\mathrm{m}$ depth during summer. Except for this season, salinities were slightly higher at E2 (Figure 2B).

At both sites, maximum values of chlorophyll- $a$ were recorded at the surface during late winter; minimum values were recorded in late autumn. As a general pattern, chlorophyll- $a$ values were slightly higher at E2 in summer and autumn; while in winter and spring, these values were higher at E1 (Figure 2C).

\section{GONADAL DEVELOPMENT AND POPULATION}

\section{STRUCTURE OF FRITILLARIA BOREALIS}

Based on the observation of a total of 1048 specimens of $F$. borealis collected along a seasonal cycle at both study sites, it was possible to describe the different stages of this species' life cycle (Figure 3). Early juveniles (I) present 
A

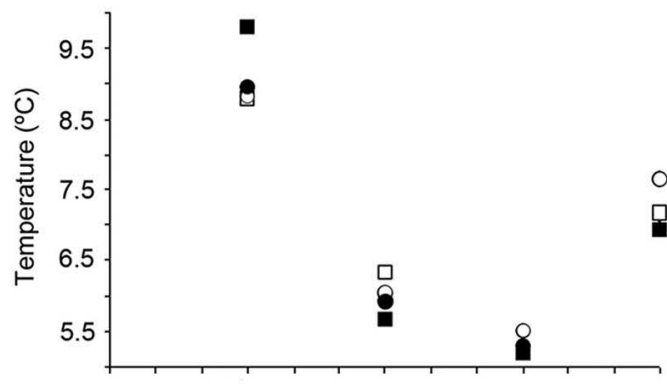

B
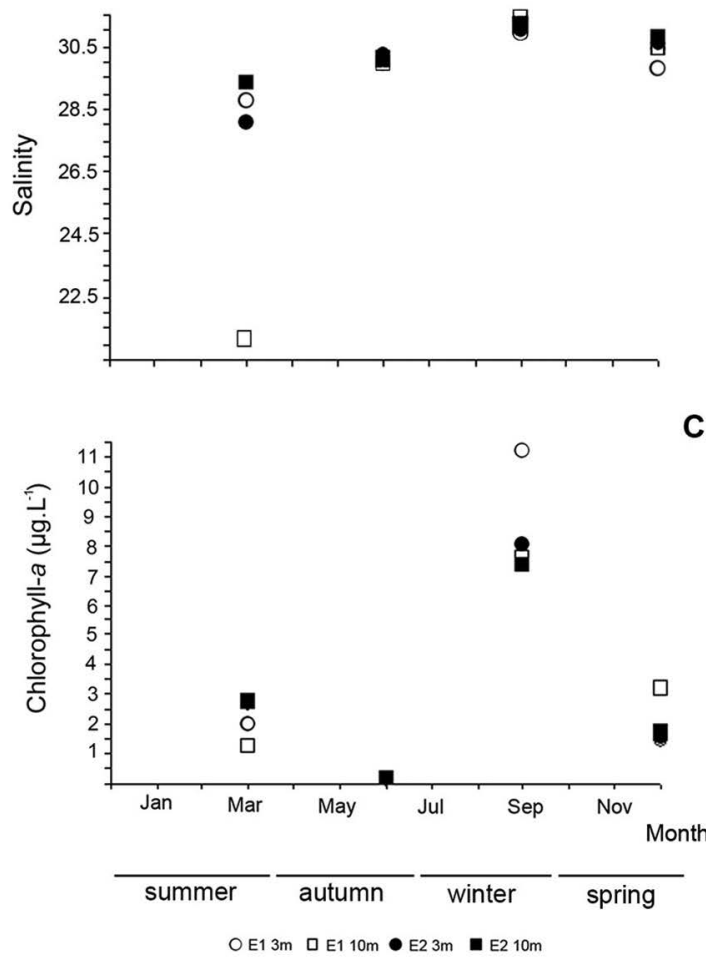

Figure 2. Seasonal variation of temperature (A), salinity (B) and chlorophyll- $a$ concentration (C) for each study site, E1 and E2, in Ushuaia Bay at surface and $10 \mathrm{~m}$ of depth.

a transparent, loose genital sac behind the digestive tract which may be empty or present a poor development of gonadal tissue (Figure 3A, B). In successive stages, the gonad, not yet differentiated or with very incipient differentiation, develops until it occupies the genital sac (Figure 3C-E). In a late juvenile stage (II), gonad differentiation occurs and the presence of ovary and testis is clearly observed (Figure 3F-H). Specimens who exhibit an early maturity stage (III) are characterized by a noticeable increase in the volume of the ovary and by an increase in the size of the lateral dorso-ventral flattened extensions of the genital sac (Figure 3I-K). These extensions are also present in juvenile stages but become clearly conspicuous in stage III. In these specimens, a V-shaped groove was observed in the posterior wall of the testis whereby the spermatozoon evacuation may begin to occur (Figure 3I). We also found specimens in which the content of the testis expands to occupy the lateral extensions of the genital sac (Figure 3K). In a late maturity stage (IV), the testis is partially or totally discharged and the rupture of the ovary wall occurs, with the subsequent expansion of its content (Figure 3L-N). In a late, brief stage, the gonad exhibits only mature oocytes (Figure $3 \mathrm{~N}$ ). Once the oocytes have been discharged, the specimen dies and the gonad is represented by a wide, transparent and flaccid genital sac; completely empty or with the presence of gonadal tissue rests (Figure 3O).

Generally, the seasonal pattern in the maturity stages structure of $F$. borealis differed between the two study sites. In late summer, at the coastal site (E1), similar percentages of juveniles I (36.3\%) and mature specimens (45.4\%) were observed; while at E2 juveniles (I) were the dominant stage (77.3\%) (Figure 4A, B). Due to the extremely low density of $F$. borealis during autumn at E1, it was not possible to determine its stage structure. At E2, juveniles (I) were dominant $(62.9 \%)$ (Figure $4 \mathrm{C})$. Contrary to that observed in summer and autumn, the percentage of juveniles (I and II) was higher at E1 in winter (81\%); while at E2 similar percentages of juveniles and mature specimens were found (50.9\% and $49.03 \%$, respectively) (Figure 4D, E). In spring, percentages of juveniles (I and II) and mature specimens were similar at both sites (E1: $52.6 \%$ and $47.3 \%$; E2: $58.7 \%$ and $41.2 \%$, respectively) (Figure $4 \mathrm{~F}, \mathrm{G}$ ). A broad overlapping of the trunk size ranges corresponding to different stages of development was observed. Particularly, the greatest overlapping of sizes occurred between juveniles II and mature individuals (Table 1).

Regarding density of $F$. borealis, its highest values were recorded in spring and summer, at both sites. At E1, density varied between a maximum of 1224.2 ind.m-3 in summer and a minimum of 8.5 ind.m-3 in autumn. Densities were always markedly higher at E2, maximum and minimum values were recorded in spring (4758.4 ind.m-3) and winter (35.8 ind.m-3), respectively (Figure 5).

The degree of maturity of juveniles differed, in each site, according to the season. Despite the high variability observed, in spring and summer juveniles I and II with a significantly larger gonadal length than those found in autumn and winter months, were observed (Figure 6AD, Table 2). During spring, juveniles I showed, at E2, 


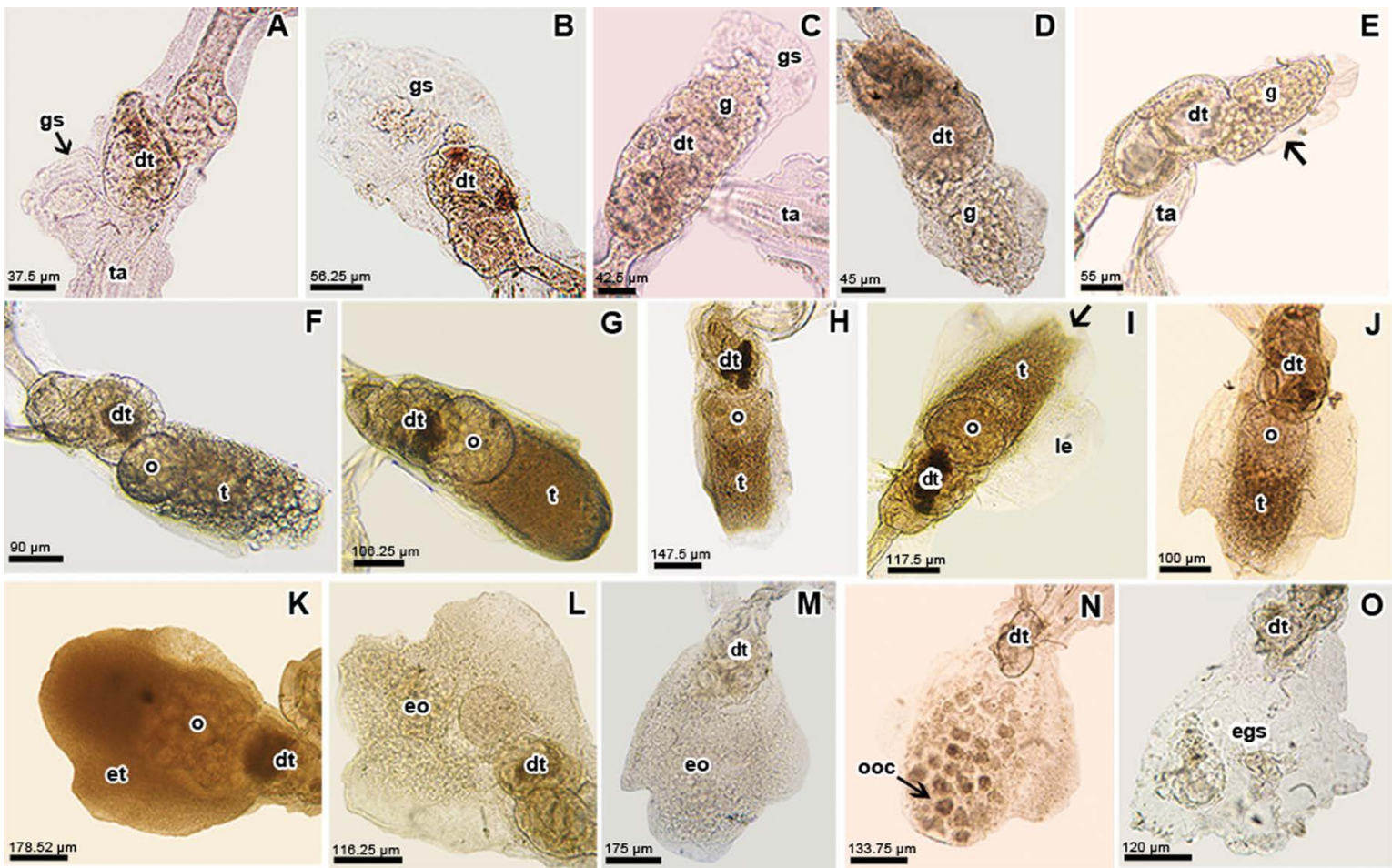

Figure 3. Maturity stages of Fritillaria borealis. Stage I (A-E) and II (F-H) correspond to juveniles and stage III (I-K) and IV (L-O) correspond to matures individuals. dt: digestive tract; eo: expanded ovary; et: expanded testis; gs: genital sac; o: ovary; ooc: oocites; t: testis; ta: tail. Arrows indicate incipient gonadal differentiation (E) and V-shaped groove in the posterior wall of the testis of individuals at stage III (I).

larger trunk sizes than those observed in other seasons (Figure 6B). The gonadal length of mature individuals (III and IV) showed, at both sites, a pattern of seasonal variation similar to that described for juveniles; being significantly larger in warm months (Table 2 ). In this case, the patterns were not clearly defined probably due to the low number of individuals in these stages, especially in autumn and winter. At both E1 and E2, individuals reached larger trunk sizes in spring (Figure 6E-H). When comparing all data obtained along the seasonal cycle for each site, no differences in the gonadal length of juveniles were observed. However, the gonadal length of mature individuals (III) was significantly larger at the coastal site. Gonadal length of individuals of stage IV did not show any significant differences (Table 2).

\section{DISCUSSION}

On the basis of the observations made of the Fritillaria borealis specimens collected in Ushuaia Bay along a seasonal cycle, it was possible to distinguish four maturity stages. The description of each stage was complemented by morphometric data of the gonad and the trunk of the specimens. This new classification exhibits some differences with respect to that proposed by WYATT (1973). Stage II includes only juvenile individuals whose testis and ovary have already differentiated; while originally individuals with mature testis (here presented as stage III) also had been included in that stage. Individuals with mature ovary and those with both gonads discharged, before classified as III and IV respectively, are now included together in stage IV. In view of the short duration of this last stage of maturity and considering that the great fragility of fully mature individuals complicates their quantification in the samples, we consider that the redefinition of stages here proposed is more representative of the maturity status of $F$. borealis populations.

In this study, the population structure and densities of F. borealis in Ushuaia Bay varied seasonally and according to the zone of the bay, coastal or external, considered. The environmental variables showed a strong seasonal pattern. The highest values of chlorophyll- $a$ were found at both sites in late winter and summer. These results are consistent with those obtained by HOFFMEYER et al. (2009), who studied the annual cycle of phytoplankton. Chlorophyll- $a$ values show a bimodal curve both on the coast and in the external zone of the bay; maximum values occur in 

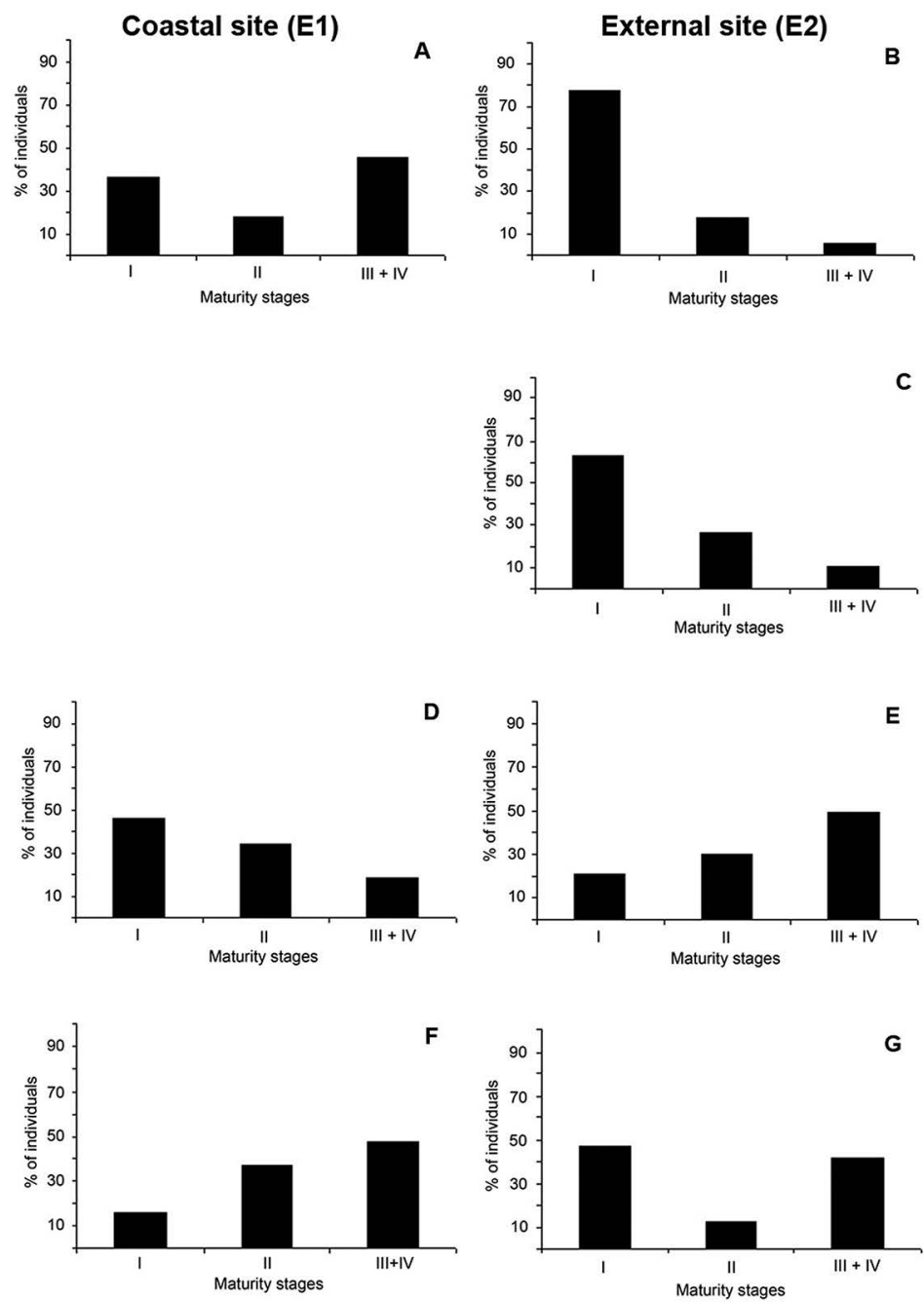

Figure 4. Percentages of juveniles (I and II) and matures (III + IV) of Fritillaria borealis at each study site, E1 (left column) and E2 (right column), during summer (A, B), autumn (C), winter (D, E) and spring (F-G) 2012.

Table 1. Mean trunk length (TL), mean gonadal length (GL) and mean gonadal width (GW) in mm of the maturity stages of $F$. borealis

\begin{tabular}{cccc}
\hline $\begin{array}{c}\text { Maturity } \\
\text { stage }\end{array}$ & $\begin{array}{c}\text { TL } \pm \text { SD } \\
(\mathbf{m m})\end{array}$ & $\begin{array}{c}\mathbf{G L} \pm \mathbf{S D} \\
\mathbf{( m m})\end{array}$ & $\begin{array}{c}\mathbf{G W} \pm \mathbf{S D} \\
\mathbf{( m m})\end{array}$ \\
\hline I & $0.36 \pm 0.12$ & $0.11 \pm 0.05$ & $\ldots$ \\
II & $0.62 \pm 0.13$ & $0.25 \pm 0.07$ & $\ldots$ \\
III & $0.80 \pm 0.14$ & $0.38 \pm 0.09$ & $0.27 \pm 0.10$ \\
IV & $0.74 \pm 0.13$ & $0.35 \pm 0.08$ & $0.25 \pm 0.08$ \\
\hline SD:
\end{tabular}

spring and late summer when conditions of light and temperature are optimal for phytoplankton development. Besides, the seasonal patterns of temperature and salinity are consistent with observations made by BIANCALANA et al., (2012, 2014) and ITURRASPE et al., (1989). When

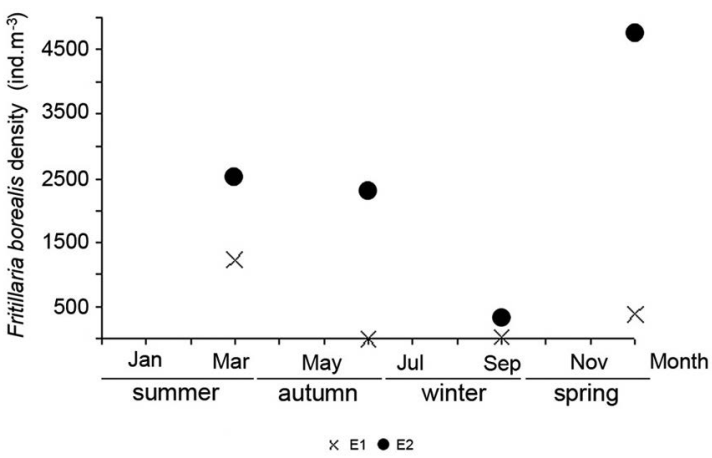

Figure 5. Seasonal variation of Fritillaria borealis density in Ushuaia Bay at both study sites, E1 and E2.

comparing the coastal and external sites, the differences in the environmental variables were less noticeable. The coastal site showed lower values of salinity and higher 
ones of temperature than those registered at the external site. These differences are mainly explained by a greater contribution of fresh water in the coastal zone and by a remarkable influence of the current from the Beagle Channel at the mouth of the bay (BIANCALANA, 2008).

The percentage of juveniles (I and II) showed a spatial and temporal pattern of variation similar to that observed for chlorophyll- $a$ values. The highest percentages were registered in summer and autumn at the external site, while in winter they were registered at the coastal site. However in spring, their percentages were similar at both sites. The association between chlorophyll- $a$ values and the percentage of juveniles could be explained by a higher recruitment of appendicularians in environments where phytoplankton food is more abundant. This bottom-up regulation has been reported frequently in populations of appendicularians (B̊̊MSTEDT et al., 2005). AGUIRRE et al. (2012) observed that the highest densities of $F$. borealis in the Beagle Channel during spring coincided with the maximum values of surface chlorophyll- $a$. In the present study, the highest densities of $F$. borealis were registered in spring and summer while the maximum values of chlorophyll- $a$ occurred in late winter. This was probably due to the fact that the winter sampling coincided with the beginning of the phytoplankton bloom. Considering that the numerical response of zooplankton occurred with a certain delay, it was not possible to register the consequent changes in the density of appendicularians until the spring sampling. In fact, the larger trunk sizes observed in the spring populations of $F$. borealis could be explained by their development in an environment with higher abundance of food.

In addition to the above-mentioned bottom-up process, it has been reported that populations of appendicularians may suffer a top-down regulation. Several studies have shown that this group constitutes a prey item for fish larvae (CAPITANIO et al., 1997; 2008; PURCELL et al. 2005). It has also been shown, experimentally, that calanoid copepods are able to feed on eggs and juveniles of appendicularians, thus altering their density and population structure (SOMMER et al., 2003; LÓPEZURRUTIA et al., 2004; STIBOR et al., 2004). Observations made using a $200 \mu \mathrm{m}$-mesh net during this seasonal cycle (Pers. Comm.) have shown that the abundance of calanoid copepods was irrelevant and frequently lower than the abundance of appendicularians. This result did not suggest a strong predation pressure by copepods. In fact, the abundance of appendicularians, markedly low on the coast as compared to the external zone in autumn, winter and spring, would be explained by competence processes with small sized taxa of zooplankton. These taxa would be the cyclopoid copepod Oithona similis (autumn), Cirripedia and Echinodermata larval stages (winter) and the cladocerans Podon leuckarti and Evadne nordmanni (spring); although their abundances were underestimated as a result of the use of the $200 \mu \mathrm{m}$-mesh net. These observations reinforced the hypothesis of the existence of bottom-up processes even though their importance can not be evaluated as larger zooplankters (including other potential predators) were not quantified.

The broad trunk size ranges presented by the different stages would suggest important intrapopulation variability in the development. Particularly, the greatest size overlapping observed between juveniles II and mature individuals (III and IV) would be indicating that the size (measured as length of trunk) is not an appropriate indicator of maturity in the mature stages. When the testis matures, the gonads experience a remarkable growth in width, so this measurement would represent a better indicator of maturity. It is noteworthy that the sizes of juveniles I and early II probably were underestimated since in most of these individuals the edges of the genital sac were broken. Individuals in the last stage of maturity (IV) showed a mean trunk size lower than those registered in the previous maturity stage (III). It was observed in the appendicularian Oikopleura dioica that during the maturation process, the trunk is slowly reabsorbed and this reabsorbed material would be invested in gonadal maturation (LOMBARD et al., 2009a). This process described in $O$. dioica could be consistent with our observations of mature individuals of F. borealis.

During the spring and summer months, at both sites, juvenile and mature individuals presented a greater gonadal development (measured as gonadal length) than those of the same size found in the autumn and winter months. This result could be explained by the increase of temperature during the warm seasons and its consequent effects on the metabolic rates of appendicularians. LOMBARD et al. (2009b) observed, experimentally, that an increase in temperature produces increased assimilation and respiration rates in $O$. dioica. As a consequence of this, the maturation process accelerates and the generation time (i.e., time between egg production and spawning) is reduced.

When comparing patterns of seasonal variation of the density of $F$. borealis at the two study sites, a mismatch 


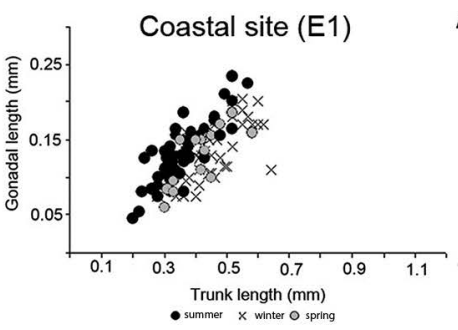

A
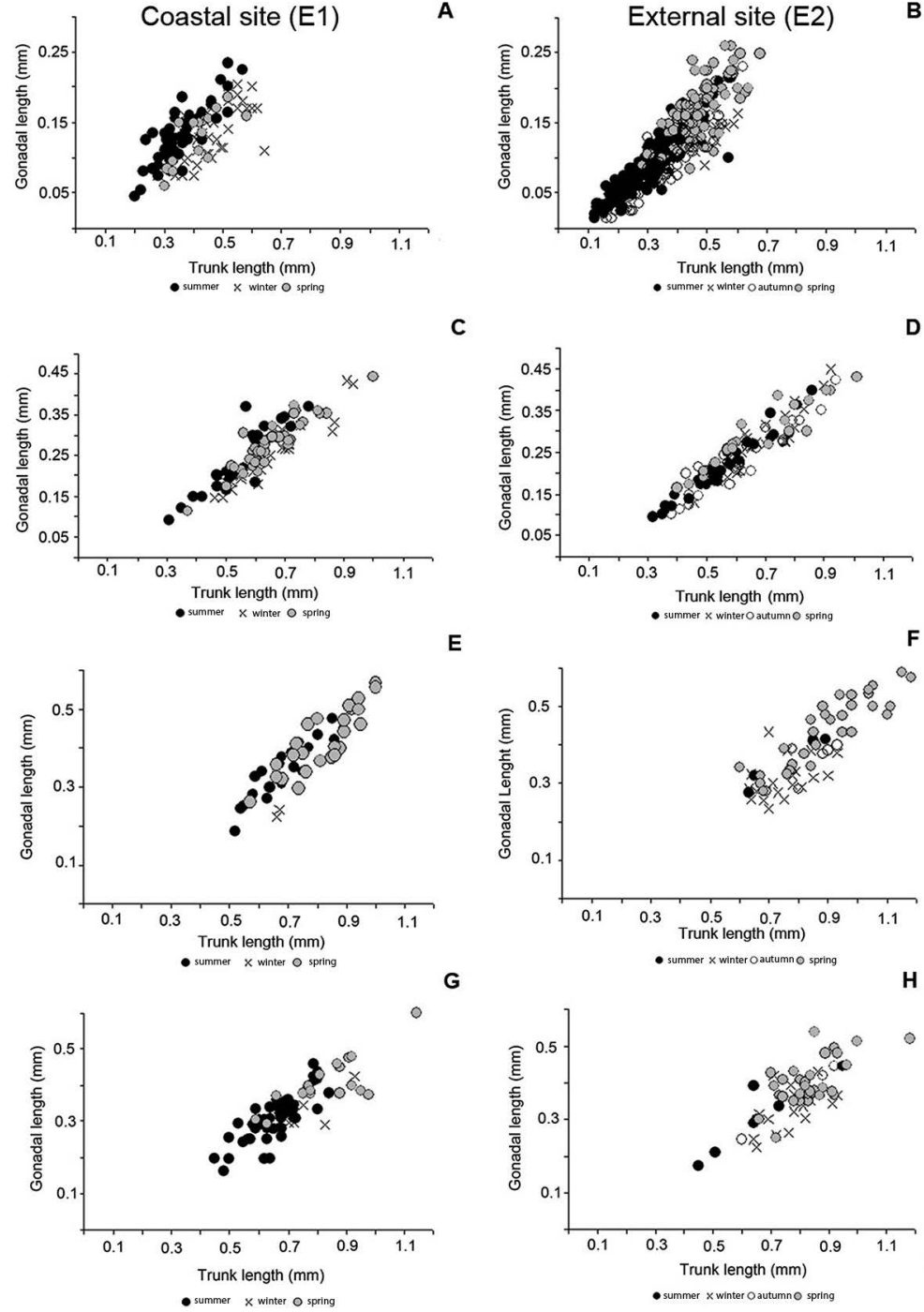

Figure 6. Seasonal variation of gonadal length related to trunk length at each study site, E1 (left column) and E2 (right column). Stage I (A, B), stage II (C, D), stage III (E, F) and stage IV (G, H).

between them was observed. On the coast, the density maximum occurred in summer and the minimum in autumn. At the external site, maximum and minimum densities occurred in spring and in winter, respectively. The mismatch found in the population structures and in the patterns of density of $F$. borealis between coastal and external sites could suggest the presence of two discernible subpopulations associated with the environmental characteristics of each zone, the coastal and the external ones. This hypothesis is coherent with the findings of BIANCALANA et al. $(2012,2014)$ and BARRÍA DE CAO et al. (2013) who have shown the presence of different mesozooplanktonic and microzooplanktonic associations in the coastal and external zones of Ushuaia Bay. Also, due to the low depths, the presence of dense forests of macroalgae (Macrocystis pyrifera) in the coastal zone may contribute to the retention of zooplankton in this area. The results obtained in this study indicate that the population structure of $F$. borealis could be influenced by levels of chlorophyll- $a$ (i.e. due to the proportion of available nanoplanktonic cells) and to bacteria densities. The northern and northwestern coast of the bay is characterized by high levels of organic matter from anthropogenic sources and nutrient enrichment, with a direct influence on phytoplanktonic biomass and composition (ESTEVES; AMIN, 2001; GIL et al., 2011). Therefore, populations of $F$. borealis would be susceptible to the influence of the anthropogenic impact on the bay. Future studies which 
Table 2. Statistical analysis of data corresponding to gonadal length of the different maturity stages of $F$. borealis in each season and study site

\begin{tabular}{lcc}
\hline ANCOVA & $\boldsymbol{p}$-values & LSD Fisher Comparisons \\
\hline Stage I at E1 & & \\
Season & $<0.0001$ & summer $>$ winter-spring $(p<0.05)$ \\
Trunk length & $<0.0001$ & \\
At E2 & & \\
Season & $<0.0001$ & \\
Trunk length & $<0.0001$ & spring $>$ summer $>$ autumn-winter \\
& & $(p<0.01)$ \\
\hline Stage II at E1 & & \\
Season & $<0.0001$ & \\
Trunk length & $<0.0001$ & spring-summer $>$ winter $(p<0.01)$ \\
At E2 & & \\
Season & $<0.0041$ & \\
Trunk length & $<0.0001$ & spring $>$ autumn-winter $(p<0.01)$ \\
\hline Stage III at E1 & & \\
Season & $<0.6673$ & spring $=$ summer $(p>0.05)$ \\
Trunk length & $<0.0001$ & \\
At E2 & & \\
Season & 0.0001 & \\
Trunk length & $<0.0001$ & spring-summer $>$ autumn $(p<0.05)$ \\
E1 vs. E2 & & \\
Study site & $<0.0001$ & E1 $>$ E2 $(p<0.05)$ \\
Trunk length & $<0.0001$ & \\
\hline Stage IV at E1 & & \\
Season & $<0.0165$ & \\
Trunk length & $<0.0001$ & spring-summer $>$ winter $(p<0.05)$ \\
At E2 & & \\
Season & 0.0141 & \\
Trunk length & $<0.0001$ & \\
\hline
\end{tabular}

investigate the population dynamic by means of more frequent samplings would clarify this hypothesis.

\section{ACKNOWLEDGMENTS}

We wish to thank the Centro Austral de Investigaciones Científicas (Ushuaia city, Tierra del Fuego, Argentina) and very especially Dra. Luciana Riccialdelli and Lic. Paola Villatarco for their collaboration with the zooplankton samplings and Captain Marcelo Peréz for his shipboard assistance. This study was partially supported by UBACYT 20020100200048 and CONICET PIP 11220110100351 grants to F. Capitanio. M. L. Presta was funded by a doctoral fellowship (Consejo Nacional de Investigaciones Científicas y Técnicas, Argentina).

\section{REFERENCES}

AGUIRRE, G.; CAPITANIO, F. L.; LOVRICH, G. A.; ESNAL, G. B. Seasonal variability of metazooplankton in coastal sub-antarctic waters (Beagle Channel). Mar. Biol. Res., v. 8, n. 4, p. 341-353, 2012.

ANTACLI, J. C.; HERNÁNDEZ, D.; SABATINI, M. Estimating copepods' abundance with paired nets: Implications of mesh size for population studies. J. Sea Res., v. 63, p. 71-77, 2011.

BALESTRINI, C.; MANZELLA, G.; LOVRICH, G. A. Simulación de corrientes en el Canal Beagle y Bahía Ushuaia, mediante un modelo bidimensional. Buenos Aires: Servicio de Hidrografía Naval, Departamento de Oceanografía. Technical Report, n. 98, p. 58, 1998.

BÁMSTEDT, U.; FYHN, H. J.; MARTINUSSEN, M. B.; MJAAVATTEN, O.; GRAHL-NIELSEN, O. Seasonal distribution, diversity and biochemical composition of appendicularians in Norwegian fjords. In: GORSKY, G.; YOUNGBLUTH, M. J.; DEIBEL, D. (Eds.). Response of Marine Ecosystems to Global Change: Ecological Impact of Appendicularians. Paris: Contemporary Publishing International, 2005. p. 227-254.

BARRÍA DE CAO, M. S.; LÓPEZ ABBATE, M. C.; PETTIGROSSO, R. E; HOFFMEYER, M. S. The planktonic ciliate community and its relationship with the environmental conditions and water quality in two bays of the Beagle Channel, Argentina. J. Mar. Biol. Ass. U. K., v. 93, n. 7, p. 1753-1760, 2013.

BIANCALANA, F. Dinámica del mesozooplancton y su regulación ambiental en las bahías Ushuaia y Golondrina. $\mathrm{Ph}$. D. Thesis, Universidad Nacional del Sur, Bahía Blanca, Buenos Aires, 2008. 195 p.

BIANCALANA, F.; DIODATO, S. L.; HOFFMEYER, M. S. Seasonal and spatial variation of mesozooplankton biomass in Ushuaia and Golondrina Bays (Beagle Channel, Argentina). Braz. J. Oceanog., v. 60, n. 1, p. 99-106, 2012.

BIANCALANA, F.; DUTTO, M. S.; BERASATEGUI, A. A; KOPPRIO, G.; HOFFMEYER, M. S. Mesozooplankton assemblages and their relationship with environmental variables: a study case in a disturbed bay (Beagle Channel, Argentina). Environ. Monit. Assess., v. 186, n. 12, p. 862947, 2014

BOLTOVSKOY, D. Atlas del zooplancton de Atlántico Sudoccidental y métodos de trabajo con el zooplancton marino. Mar del Plata: INIDEP, 1981. 936 p.

CAPITANIO, F. L.; CURELOVICH, J.; TRESGUERRES, M.; NEGRI, R.; VIÑAS, M.D.; ESNAL, G. B. Seasonal cycle of appendicularians at a coastal station $\left(38^{\circ} 28^{\prime} \mathrm{S} 57^{\circ} 41^{\prime} \mathrm{W}\right)$ of the SW Atlantic Ocean. Bull. Mar. Sci., v. 82, n. 2, p. 171$184,2008$.

CAPITANIO, F.L.; PÁJARO, M.; ESNAL, G.B.Appendicularians in the diet of anchovy Engraulis anchoita in the Argentine Sea. Sci. Mar., v. 61, n. 1, p. 9-15, 1997.

DIODATO, S.L.Incorporación de fitoplancton y microzooplancton por el mesozooplancton en Bahía Ushuaia, Tierra del Fuego. Tesina de Licenciatura, Universidad Nacional del Sur, Bahía Blanca, Buenos Aires, 2008. 
DI MAURO, R.; CAPITANIO, F. L.; VIÑAS, M. D. Capture efficiency for small dominant mesozooplankters (Copepoda, Appendicularia) off Buenos Aires Province $\left(34^{\circ} \mathrm{S}-41^{\circ} \mathrm{S}\right)$, Argentine Sea, using two plankton mesh sizes. Braz. J. Oceanog., v. 57, n. 3, p. 205-214, 2009.

ESTEVEZ, J. L.; AMIN, O. Evaluación de la Contaminación Urbana de las Bahías de Ushuaia, Encerrada y Golondrina (Provincia de Tierra del Fuego, Antártica e Islas del Atlántico Sud). Consolidación e Implantación del Plan de la Zona Costera Patagónica (PMZCP) - ARG/02/G31 - GEF/PNUD. CD-ROM. 2001.

FENAUX, R. Cycle vital, croissance et production chez Fritillaria pellucida (Appendicularia) dans la baie de Villefranche-surMer, France. Mar. Biol., v. 34, p. 229-238, 1976.

FENAUX, R. Les Appendiculaires des mers d'Europe et du Bassin Méditerranéen. Paris: Masson et Cie Editeurs, 1967. 113 p.

FENAUX, R. The classification of Appendicularia. In: BONE, Q. (Ed.). The biology of pelagic tunicates. Oxford: Oxford University Press, 1998a. p. 295-306.

FENAUX, R.; BONE, Q.; DEIBEL, D. Appendicularian distribution and zoogeography. In: BONE, Q. (Ed.). The biology of pelagic tunicates. Oxford: Oxford University Press, 1998b. p. 251-271.

GIL, M.; TORRES, A. I.; AMÍN, O.; ESTEVES, J. L. Assessment of recent sediment influence in an urban polluted subantarctic coastal ecosystem. Beagle Channel (Southern Argentina). Mar. Pollut. Bull., v. 62, n. 1, p. 201-207, 2011.

HOFFMEYER, M. S.; SMORZEÑUK, N; COMOGLIO, L. I.; GOMEZ, E. A. Condiciones de temperatura, salinidad y clorofila- $a$ en Bahía Ushuaia. Argentina - marzo 2006 a febrero 2008. Poster. XIII COLACMAR, La Habana, Cuba, 2009.

HOLM-HANSEN, O.; LORENZEN, C.J.; HOLMES, R.W.; STRICKLAND, J. D. H. Fluorometric determination of chlorophyll. J. Cons. Perm. Int. Explor. Mer., v. 30, p. 3-15, 1965.

ITURRASPE, R.; SOTTINI, R.; SCHROEDER, C.; ESCOBAR, J. Generación de información hidroclimática en Tierra del Fuego. In: Hidrología y variables climáticas del Territorio de Tierra del Fuego. Información básica. Publ. Científ. 7. Ushuaia: CADIC- CONICET, 1989.
LOHMSANN, H. Die Appendicularien der Plankton-Expedition. Ergebn. Plankton-Exp. Humboldt-Stiftung, v. 2, p. 1-148, 1896.

LOMBARD, F.; RENAUD, F.; SAINSBURY, C.; SCIANDRA, A.; GORSKY, G. Appendicularian ecophysiology I: Food concentration dependent clearance rate, assimilation efficiency, growth and reproduction of Oikopleura dioica. J. Mar. Sys., v. 78, n. 4, p. 606-616, 2009a.

LOMBARD, F.; SCIANDRA, A.; GORSKY, G. Appendicularian ecophysiology II: Modeling nutrition, metabolism, growth and reproduction of the appendicularian Oikopleura dioica. J. Mar. Sys., v. 78, n. 4, p. 617-629, 2009 b.

LÓPEZ-URRUTIA, A.; HARRIS, R.; SMITH, T. Predation by calanoid copepods on the appendicularian Oikopleura dioica. Limnol. Oceanogr., v. 49, p. 303-307, 2004.

LUCHINI, L.; WICKI, G. A. Evaluación del potencial para acuicultura en la Provincia de Tierra del Fuego. Información Básica. Buenos Aires: Secretaría de Agricultura, Ganadería, Pesca y Alimentos (SAGPyA), 2002. 29 p.

MARTINUCCI, G.; BRENA, C.; CIMA, F.; BURIGHEL, $\mathrm{P}$. Synchronous spermatogenesis in appendicularians. In: GORSKY, G.; YOUNGBLUTH, M. J.; DEIBEL, D. (Eds.). Response of Marine Ecosystems to Global Change: Ecological Impact of Appendicularians. Paris: Contemporary Publishing International, 2005. p. 113-125.

PURCELL, J. E.; STURDEVANT, M.V.; GALT, C. P. A review of appendicularians as prey of fish and invertebrate predators. In: GORSKY, G.; YOUNGBLUTH, M. J.; DEIBEL, D. (Eds). Response of marine ecosystems to global change: ecological impact of appendicularians. Paris: Contemporary Publishing International, 2005. p. 359-435.

SOMMER, F.; HANSEN, T.; FEUCHTMAYR, H.; SANTER, B.; TOKLE, N.; SOMMER, U. Do calanoid copepods suppress appendicularians in the coastal ocean? J. Plankton Res., v. 25, n. 7, p. 869-871, 2003.

STIBOR, H.; VADSTEIN, O.; LIPPERT, B.; ROEDERER, W.; OLSEN, Y. Calanoid copepods and nutrient enrichment determine population dynamics of the appendicularian Oikopleura dioca: a mesocosm experiment. Mar. Ecol. Prog. Ser., v. 270, p. 209-215, 2004.

WYATT, T. The biology of Oikopleura dioica and Fritillaria borealis in the Southem Bight. Mar. Biol., v. 22, p. 137-158, 1973. 